\author{
Evangelos SISKOS, \\ Konstantia DARVIDOU
}

\title{
BILATERAL TRADE \\ AND ENERGY RELATIONS BETWEEN THE EU AND THE COUNTRIES OF THE CASPIAN SEA REGION
}

\begin{abstract}
The European Union and the Caspian countries are important trade partners, although there is still potential for improvement of the cooperation considering the energy security and other issues. The paper analyses trends and structure of trade relations of the EU and Caspian countries. The trade between the regions is about 370 billion dollars. Exports of fuels to the EU are the main component of the trade between the regions. Therefore energy transportation projects are an important issue in the agenda for the international relations. A gravity model for the exports of fuels is presented. The model considers demand in the EU importing country, total fuel exports of an exporting Caspian country as an indicator of exporting supply capacities and in some cases energy self-sufficiency of an importing country. Distance turned out to make an insignificant effect on the energy trade. The analysis helps to determine undertraded and successfully exploited bilateral energy trade links between the individual EU and Caspian coun-
\end{abstract}

(C) Evangelos Siskos, Konstantia Darvidou, 2020.

Siskos Evangelos, D. Sc. Econ, Professor, Department of International and European Economic Studies (Kozani), University of Western Macedonia, Greece. ORCID: https://orcid.org/0000-00025221-4444, Email: esiskos@uowm.gr.

Darvidou Konstantia, Ph. D. of International Economic Relations, University of Western Macedonia, Greece. ORCID: https://orcid.org/0000-0002-5221-4444, Email: globaleugr@gmail.com. 

and the countries of the Caspian Sea region

tries. The model showed that Greece is among the most relatively intensive importers of fuels from the Caspian region.

\section{Key words:} model.

International trade, energy trade, European Union, Caspian region, gravity

JEL: F10, F13, F15, Q4.

\section{Introduction}

The EU (European Union) and the Caspian countries are either neighbours or at least have some geographical proximity. There is an institutional anchor to the EU for some of the countries: Eastern Partnership and European Neighbourhood policy (Azerbaigan), Partnership and Cooperation agreements (Azarbaijan, Russia), Enhanced Partnership and Cooperation Agreement (Kazakhstan) etc. Simultaneously the geopolitical tension because of hybrid war of Russia with Ukraine resulted in sanctions and other restrictive measures between Russia and the EU. Also Iran was a target for sanctions for nuclear proliferation activities. Nevertheless energy security issue is a basis for international trade relations between the regions. Relations with other 3 Caspian countries (Azerbaijan, Kazakhstan and Turkmenistan) can be a solution for the problem of diversification of energy supplies for the EU.

The paper is devoted to the analysis trade relations of the EU and Caspian countries, their role, structure and trends. The particular interest is to determine trends and factors of the bilateral trade in oil and gas, which constitutes the main part of the exports of the 5 countries to the EU. The paper starts with analysis of trade in goods and services in general and fuels in particular, and continues by modelling oil and gas exports of the Caspian countries to the EU. Estimation of efficiency and underexploited potential for specific bilateral energy links can contribute to the further development of bilateral economic relations between the regions. 


\section{Literature review}

The current research of the EU-Caspian region relations largely concentrates on geopolitical issues and past developments in energy cooperation. A particular attention is paid to oil and gas transportation.

The main oil transport routes (except eastward routes) included:

- Tengiz-Novorossiysk (CPC Pipeline) Kazakhstan-Russia;

- Baku-Tbilisi-Ceyhan (BTC Pipeline) Azerbaijan-Georgia-Turkey;

- Atyrau-Samara Pipeline Kazakhstan-Russia;

- Baku-Batumi Azerbaijan-Georgia: by Train;

- Baku- Novorossiysk Pipeline Azerbaijan-Russia;

- Neka, Iran: deliveries by barge;

- Kazakh shipments by barge to Baku and Makhachkala (Emadi and Nezhad (2011)).

As for natural gas pipeline projects, earlier the Nabucco (favoured by western countries) through Turkey and South Stream (initiated by Russia) through the Black Sea to Bulgaria and further were the two main competing projects for transporting natural gas. Instead they decided to construct the TransAdriatic Pipeline (TAP) through Greece, Albania and the Adriatic Sea to Italy with a capacity 10-20 billion cubic meters with interconnector to Bulgaria and the Ionian Adriatic Pipeline (IAP) to Montenegro and Croatia. And Russia instead decided to build the Turkish Stream in the Black Sea in addition to the existing Blue Stream pipeline. Other pipelines included Trans-Anatolian pipeline in Turkey (TANAP) and the Trans-Caspian pipeline (TCP) project (Ibrayeva et al (2018)). South Caucasus Pipeline (SCP or Baku-Tbilisi-Erzurum pipeline), TANAP and TAP are the elements of the Southern Gas Corridor initiative. The Central Asia Center gas pipeline system enables to transport the natural gas from Turkmenistan to Russia.

Papava et al. (2009) mentioned the factors of increasing interest of the EU for energy cooperation with the Caspian countries: decreasing domestic production of oil and gas, unstable relations with Russia and the upward fuel price trend in the analysed period. Caspian countries were interested in diversification of their export markets, but lacked alternative export infrastructure. Papava et al. (2009) recommended that the EU should play the leading role in energy security developing policies; apply financial instruments of the EU, the European Investment Bank, the European Bank for Reconstruction and Development, and other international financial institutions; solve the gas disputes between Russia and 

and the countries of the Caspian Sea region

Ukraine, and Russia and Belarus through multinational cooperation; increase focus on energy resources of the Caspian region for diversification of supplies; invest in new sources and transportation facilities although avoiding duplication of pipelines.

Locatelli (2010) wrote that Russia favoured bilateral relations with main partners in the EU, which could fit the energy security strategies of those member-states but would be contrary to the overall EU policy. South Corridor would decrease dependence of the EU on Russian energy exports, but the initiative would be affected by geopolitical factors.

Erdogdu (2010) wrote that South Stream and Nabucco should not have been treated only as mutually exclusive pipeline projects because of the EU demand for gas is large enough. But there should have been more supply for Nabucco than only from Azerbaijan to make it feasible. Another obstacle was opposition from Russia and even some of the EU member states. There was a mixed attitude of Turkey to Nabucco, which tried to get a share of the transported gas at a reasonable price, to tax gas transit and to link the project to the accession negotiations. The suggestion was for the EU to apply a united energy policy instead of just coordinated policy which would not be enough.

Ikonnikova (2007) stated that investments in the gas industry in the Caspian region are mainly driven by strategic considerations to improve the bargaining position. On the other hand there is an underinvestment in in capacities of unreliable parties which is offset by overinvestment in bypasses. For example TCP and Nabucco were treated as bypasses to transport fuels from the Caspian region instead of transit through Russia. To avoid this situation Russia offered price concessions and suggested to transit Turkmenian gas.

Mangott (2010) wrote that the strategies to enhance energy security of the EU and Russia are only partially complementary and usually it is a zero-sumgame and mutual dependency. Excluding imports of gas from Iran would mean growing dependency of the EU on Russia. Other recommendations included possibility of merger of the northern branch of South Stream and Nabucco, and modernization of Ukrainian gas pipeline.

Hannes (2010) analysed the notion of the resource curse and applicability of it to the Caspian states considering the issues of transition to democracy and market economy, and further made proposal about how the resource curse could be overcome.

Koolaee (2011) noted that Russia misused energy dependency of other countries and could threaten cutting off energy exports for political reasons. The assessments of Russian strategy towards the EU varied from increasing dependence of Europe on its energy exports to strengthening cooperation with Europe against the United States. That was the reason for the EU to diversify its 
energy supplies. Under the pressure of US Iran sought cooperation with the EU, Russia and China. And Turkey benefited as a bridge between Asia and Europe.

Emadi and Nezhad (2011) developed a system dynamics model. They concluded that political conflicts are the most important variable affecting foreign investments and energy developments in the Caspian region. The other considered driving forces included foreign investment, international oil price, lead time, export route capacity and proven reserves. They claimed that for example the pipelines to the Mediterranean region and to the Georgian Black Sea coast are the most competitive solution for Azerbaijan. They also suggested that the $\mathrm{Ka}$ zakhstan-China pipeline is a route of a lower attractiveness than the route to the Mediterranean region and to the Georgian Black Sea. There are some difficulties for companies transporting drilling and other large equipment for oil and gas production to the Caspian Sea because the Russian Volga-Don canal system from the Black Sea is actually the only maritime route into the Caspian sea. Foreign investments played more important role for the oil and gas industry in Azerbaijan and Kazakhstan than in other countries of the region. They noted that despite formally Russia is a Caspian country its exports from the region accounted for only $3 \%$ of its total oil exports.

Costel (2011) described the main pipeline project in the Black Sea region and wrote that increasing oil exports from the Caspian region could increase the tankers passage through the Bosphoros strait, but the proposed pipeline projects could decrease environmental risks and ensure energy supply security in the region.

Stanbekov and Kotilko (2016) made a proposal that 5 Caspian countries can suggest their own projects for extraction of hydrocarbons in the Caspian Sea with the following either selection of the best project or combining the applied projects. They suggested formulas for joint participation of the countries based on the shares of the sea surface and compensation of possible environmental damage.

lbrayeva et al (2018) compared three main directions of transporting energy resources through the Caspian Sea and further to Europe: through Russian pipelines to Europe, by trans-Caspian pipelines, via Iran and Turkey (or even through the Persian Gulf ports). Also Trans-Adriatic Pipeline (TAP) project was treated as the final leg of a pipeline for gas from the Caspian Sea to European markets. Ibrayeva et al (2018) noted that development of the Caspian region energy resources is still complicated by the lack of export pipelines, transit complications, market uncertainties and political, legal and supply security issues. Various parties have their own problems and strategies. In particular since Russia has few energy resources on the Caspian seashore it developed a strategy of involvement if energy business of other Caspian countries in a form of joint production and granting transit. On the other hand the EU-Caspian energy structure as a part of the Southern Corridor is treated as a counterweight to Russia. Meanwhile Iran faced the problem of sanctions which blocked foreign investments. 

and the countries of the Caspian Sea region

Azerbaijan planned to increase gas production by the Shah Deniz Phase 2 project. Kazakhstan has a traditional influence by Russia and growing potential for energy cooperation with China. Turkmenistan can benefit from Trans-Caspian pipeline, but the issue of demarcation of the Caspian Sea with Azerbaijan provided a stress in bilateral relations.

Jahangir and Dural (2018) analysed the impact of oil and gas price and exports on the economic growth in the Caspian region. They concluded that the reserve, production, price, and export of oil and natural gas jointly affect the GDP. But only oil price and natural gas production have an individual effect on the GDP.

\section{Methodology}

Structural analysis of the UNCTAD statistical data is used to assess the trends in the merchandise trade between the two regions. The data is analysed across the time, by individual Caspian countries members and groups of products. The importance of the trade with Caspian region for the EU and the trade balances are considered too. A similar approach is used for international trade in services, although the data is provided by the Eurostat and is less comprehensive.

Energy self-sufficiency of the EU and Caspian countries is compared to assess the basis for the energy trade. We also considered the share of fuel exports in the oil and gas industries of the Caspian countries to assess their export openness.

Correlation and regression analysis is used to find out determinants of fuel exports from the Caspian countries to the EU within a gravity model approach. The dependent variable is the bilateral exports of fuels in million dollars (BFE) in 2018. The source of data is the UNCTAD.

The analysed independent variables are:

- GDP - GDP of the EU importing country (PPP method) in billion dollars in 2017 as an indicator of demand (source: World Bank World Development Indicators);

- TFE - Total fuel exports of an exporting Caspian country in million dollars in 2018 as an indicator of exporting supply capacities (source: UNCTAD);

- D- Distance between geographical centres of countries, $\mathrm{km}$ (source: DistanceFromTo: https://www.distancefromto.net/) - it is measured as a distance between geographical centres of countries (except for Rus- 
sia where the distances between the Ural Federal District - the main origin of mineral fuels and the capitals of importing countries are considered);

- ESS - Energy self-sufficiency of the EU importing country in \% in 2016 (source: 2019 Energy Statistics Pocketbook).

The multi-country model is complemented by country-specific models. The actual value of bilateral fuel exports from the Caspian countries and the value estimated with the multi-country regression model are compared to assess which bilateral links are overtraded or undertraded. Overtrading means specialization on delivery to particular importing countries, while undertrading means either potential for strengthening international energy trade links or lack of transportation capacities.

\section{Results}

\section{Trade relations between the EU and Caspian countries}

The tables 1 and 2 show the bilateral merchandise trade trends in 20082018. The EU trade with the 5 Caspian countries is about 370 billion dollars. It accounts for $1.9 \%$ of the total exports of the EU countries and $3.9 \%$ of its imports. The share for the EU exports peaked two times. The first peak was in 2008. It was followed by the crisis. The second peak was in 2012-2013. Then the hybrid war of Russia with Ukraine and the sanctions against Russia and falling fuel prices decreased the market size of most of the analysed countries. Falling energy prices also resulted in decrease of the Caspian countries' share in the EU imports after 2013. Trade with Iran was affected by the developments in the sanctions against it.

In 2008-2018 there was an absolute decrease in the EU exports to almost all the 5 countries ranging from almost flat trend in exports to Azerbaijan and Turkmenistan to more than 1.5 times drop in exports to Iran and Russia. Imports from Turkmenistan dropped 7 times, from Iran 2 times, from Russia by $1 / 4$, and there was a smaller decrease in the imports from Azerbaijan and Kazakhstan.

In 2018 Russia was the largest market for the EU exports of goods among the Caspian countries. It was followed by Iran and Kazakhstan. Russia and Kazakhstan were the main suppliers from the Caspian region. The EU has a trade deficit in most cases except with Turkmenistan and almost a balanced trade with Iran. The trade deficit has decreased by about $\$ 66$ billion since 2011 following the fuel price trends. 
Table 1

The EU exports of goods to the Caspian countries, $\$$ billion

\begin{tabular}{|l|c|c|c|c|c|c|c|c|c|c|c|}
\hline \multicolumn{1}{|c|}{ Partner } & 2008 & 2009 & 2010 & 2011 & 2012 & 2013 & 2014 & 2015 & 2016 & 2017 & 2018 \\
\hline Azerbaijan & 3.0 & 2.2 & 3.1 & 3.9 & 3.8 & 5.0 & 4.6 & 3.8 & 2.1 & 1.9 & 3.1 \\
\hline $\begin{array}{l}\text { Iran (Islamic Repub- } \\
\text { lic of) }\end{array}$ & 16.6 & 14.5 & 15.2 & 15.1 & 9.8 & 7.6 & 8.7 & 7.1 & 9.3 & 12.3 & 10.5 \\
\hline Kazakhstan & 8.3 & 7.5 & 6.9 & 8.7 & 9.1 & 10.2 & 8.9 & 6.8 & 5.6 & 5.7 & 6.8 \\
\hline Russian Federation & 151.8 & 90.9 & 113.1 & 150.5 & 157.9 & 159.5 & 136.9 & 80.9 & 78.8 & 96.8 & 99.5 \\
\hline Turkmenistan & 0.7 & 1.1 & 1.0 & 1.3 & 1.8 & 1.6 & 1.7 & 1.2 & 1.3 & 1.0 & 0.6 \\
\hline $\begin{array}{l}\text { Total for Caspian } \\
\text { countries }\end{array}$ & 180.4 & 116.2 & 139.3 & 179.5 & 182.5 & 183.9 & 160.8 & 99.9 & 97.1 & 117.8 & 120.6 \\
\hline $\begin{array}{l}\text { Share of merchan- } \\
\text { dise exports to the } \\
\begin{array}{l}\text { Caspian countries in } \\
\text { the extra EU-28 } \\
\text { trade }\end{array}\end{array}$ & 3.0 & 2.5 & 2.7 & 2.9 & 3.1 & 3.0 & 2.6 & 1.9 & 1.8 & 2.0 & 1.9 \\
\hline
\end{tabular}

Source: UNCTAD and authors' calculations.

Table 2

The EU imports of goods from the Caspian countries, $\$$ billion

\begin{tabular}{|l|c|c|c|c|c|c|c|c|c|c|c|}
\hline \multicolumn{1}{|c|}{ Partner } & 2008 & 2009 & 2010 & 2011 & 2012 & 2013 & 2014 & 2015 & 2016 & 2017 & 2018 \\
\hline Azerbaijan & 16.1 & 10.5 & 13.3 & 21.6 & 18.3 & 18.9 & 17.4 & 11.9 & 8.5 & 10.6 & 13.6 \\
\hline $\begin{array}{l}\text { Iran (Islamic Re- } \\
\text { public of) }\end{array}$ & 22.6 & 12.8 & 18.5 & 23.4 & 7.4 & 1.2 & 1.6 & 1.4 & 6.0 & 11.3 & 11.3 \\
\hline Kazakhstan & 29.0 & 16.6 & 22.7 & 34.2 & 34.4 & 35.7 & 35.9 & 20.8 & 15.9 & 22.1 & 27.4 \\
\hline Russian Federation & 271.7 & 177.1 & 230.2 & 295.6 & 296.0 & 293.0 & 263.0 & 164.7 & 139.1 & 161.6 & 198.0 \\
\hline Turkmenistan & 2.2 & 0.7 & 0.5 & 0.6 & 0.9 & 1.2 & 1.1 & 0.5 & 0.7 & 0.3 & 0.3 \\
\hline $\begin{array}{l}\text { Total for Caspian } \\
\text { countries }\end{array}$ & 341.6 & 217.8 & 285.3 & 375.5 & 357.0 & 350.0 & 319.0 & 199.2 & 170.1 & 205.9 & 250.6 \\
\hline $\begin{array}{l}\text { Share of merchan- } \\
\text { dise imports from } \\
\text { the Caspian coun- } \\
\text { tries the extra EU- } \\
\text { 28 trade }\end{array}$ & 5.4 & 4.6 & 5.3 & 6.0 & 6.1 & 5.9 & 5.3 & 3.8 & 3.3 & 3.6 & 3.9 \\
\hline
\end{tabular}

Source: UNCTAD and authors' calculations.

The table 3 provides the data about the structure of the EU exports and imports of goods to the Caspian countries. The EU exports mostly manufactured goods including machinery and transport equipment, and chemical products to the Caspian countries, and imports mostly fuels. The Caspian countries are an 
important source of fuels, and also ores and metals for the EU. In 20018 Russia supplied almost $20 \%$ of fuels imported to the EU, Kazakhstan $-3.4 \%$, Azerbaijan $-1.8 \%$, Iran $-1.3 \%$ and Turkmenistan - only $0.03 \%$.

The structures of the EU exports to the Caspian region do not vary much across the importing countries. Imports from Russia are the most diverse by product groups (74\% of them are fuels). Imports from Azerbaijan and Kazakhstan are almost completely fuel products (99\% and $92 \%)$.

Table 3

Structure of the EU merchandise trade with the Caspian countries, 2018

\begin{tabular}{|l|c|c|c|c|c|c|}
\hline \multicolumn{1}{|c|}{$\begin{array}{c}\text { Type of } \\
\text { goods }\end{array}$} & $\begin{array}{c}\text { EU ex- } \\
\text { ports to } \\
\text { the Cas- } \\
\text { pian } \\
\text { countries, } \\
\text { \$ billion }\end{array}$ & $\begin{array}{c}\text { Commodity } \\
\text { structure of ex- } \\
\text { ports, \% EU ex- } \\
\text { ports to the } \\
\text { Caspian coun- } \\
\text { tries }\end{array}$ & $\begin{array}{c}\text { EU ex- } \\
\text { ports to } \\
\text { the Cas- } \\
\text { pian coun- } \\
\text { tries, \% to- } \\
\text { tal EU ex- } \\
\text { ports }\end{array}$ & $\begin{array}{c}\text { EU im- } \\
\text { ports from } \\
\text { the Cas- } \\
\text { pian } \\
\text { countries, } \\
\text { \$ billion }\end{array}$ & $\begin{array}{c}\text { Commodity } \\
\text { structure of im- } \\
\text { ports, \% EU im- } \\
\text { ports from the } \\
\text { Caspian coun- } \\
\text { tries }\end{array}$ & $\begin{array}{c}\text { EU im- } \\
\text { ports from } \\
\text { the Cas- } \\
\text { pian coun- } \\
\text { tries, \% to- } \\
\text { tal EU im- } \\
\text { ports }\end{array}$ \\
\hline All products & 120.6 & 100.0 & 1.9 & 250.6 & 100.0 & 3.9 \\
\hline Food & 7.8 & 5,06 & 1.3 & 3.8 & 1.5 & 0.6 \\
\hline $\begin{array}{l}\text { Agricultural } \\
\text { raw materi- } \\
\text { als }\end{array}$ & 1.3 & 0,84 & 1.5 & 3.0 & 1.2 & 3.3 \\
\hline $\begin{array}{l}\text { Ores and } \\
\text { metals }\end{array}$ & 0.9 & 0,58 & 0.5 & 14.2 & 5.7 & 6.3 \\
\hline Fuels & 1.1 & 0,71 & 0.3 & 194.6 & 77.7 & 26.5 \\
\hline $\begin{array}{l}\text { Manufac- } \\
\text { tured goods }\end{array}$ & 107.0 & 69,4 & 2.2 & 24.1 & 9.6 & 0.5 \\
\hline $\begin{array}{l}\text { Chemical } \\
\text { products }\end{array}$ & 24.2 & 15,7 & 2.3 & 8.1 & 3.2 & 0.9 \\
\hline $\begin{array}{l}\text { Machinery } \\
\text { and trans- } \\
\text { port equip- } \\
\text { ment }\end{array}$ & 55.9 & 3,62 & 2.3 & 3.0 & 1.2 & 0.1 \\
\hline $\begin{array}{l}\text { Iron and } \\
\text { steel }\end{array}$ & 1.8 & 1,17 & 1.1 & 8.3 & 3.3 & 4.6 \\
\hline $\begin{array}{l}\text { Textile fi- } \\
\text { bres, yarn, } \\
\text { fabrics and } \\
\text { clothing }\end{array}$ & 4.5 & 2,92 & 2.0 & 0.3 & & 0.1 \\
\hline
\end{tabular}

Source: UNCTAD and authors' calculations. 

and the countries of the Caspian Sea region

In 2017 unlike in trade in goods the EU had trade surpluses with all the Caspian countries, although it did not offset the trade deficit in goods (see table 4). Russia, Kazakhstan and Iran are large markets are important importers of the EU services. As for the types of services, the EU exported mostly travel services to Russia (the share in the bilateral exports was $29 \%$ ) and imported transports services from it (37\%). The EU's trade in services with the Caspian countries turned out to be more stable than trade in goods (see table 5).

Table 4

Geographical structure of the trade of the EU in services with the Caspian countries, 2017, $€$ billion

\begin{tabular}{|l|c|c|c|}
\hline \multicolumn{1}{|c|}{ Partner } & $\begin{array}{c}\text { EU exports } \\
\text { of services }\end{array}$ & $\begin{array}{c}\text { EU import } \\
\text { of services }\end{array}$ & $\begin{array}{c}\text { EU balance } \\
\text { of trade in services }\end{array}$ \\
\hline Russia & 29.1 & 12.6 & 16.5 \\
\hline Kazakhstan & 2.8 & 1.0 & 1.8 \\
\hline Turkmenistan & 0.1 & 0.0 & 0.0 \\
\hline Iran & 1.9 & 1.1 & 0.8 \\
\hline Azerbaijan & 1.1 & 0.6 & 0.5 \\
\hline $\begin{array}{l}\text { Total for the Caspian } \\
\text { Countries }\end{array}$ & 35.0 & 15.3 & 19.7 \\
\hline $\begin{array}{l}\text { Share of services trade } \\
\text { with Caspian countries } \\
\text { in the extra EU-28 trade }\end{array}$ & 3.8 & 2.1 & 10.3 \\
\hline
\end{tabular}

Source: Eurostat and authors' calculations.

Table 5

Trends in the trade of the EU in services and travel services with the Caspian countries, $€$ billion

\begin{tabular}{|l|c|c|c|c|c|c|c|c|}
\hline \multicolumn{1}{|c|}{ Indicator } & 2010 & 2011 & 2012 & 2013 & 2014 & 2015 & 2016 & 2017 \\
\hline $\begin{array}{l}\text { EU exports of services } \\
\text { to the Caspian coun- } \\
\text { tries, } € \text { billion }\end{array}$ & 26.2 & 29.9 & 34.2 & 36.2 & 35.5 & 30.6 & 32.2 & 35.0 \\
\hline $\begin{array}{l}\text { EU imports of services } \\
\text { from the Caspian } \\
\text { countries, } € \text { billion }\end{array}$ & 14.8 & 15.3 & 16.1 & 16.3 & 14.8 & 14.4 & 13.5 & 15.3 \\
\hline
\end{tabular}




\begin{tabular}{|l|l|l|l|l|l|l|l|l|}
\hline \hline \multicolumn{1}{|c|}{ Indicator } & 2010 & 2011 & 2012 & 2013 & 2014 & 2015 & 2016 & 2017 \\
\hline $\begin{array}{l}\text { EU balance of trade in } \\
\text { services with the Cas- } \\
\text { pian countries, € billion }\end{array}$ & 11.4 & 14.6 & 18.1 & 20.0 & 20.7 & 16.3 & 18.7 & 19.7 \\
\hline $\begin{array}{l}\text { EU exports of services } \\
\text { to the Caspian coun- } \\
\text { tries, \% of extra-EU-28 } \\
\text { exports of services }\end{array}$ & 4.6 & 4.9 & 5.0 & 5.0 & 4.6 & 3.5 & 3.7 & 3.8 \\
\hline $\begin{array}{l}\text { EU imports of services } \\
\text { to the Caspian coun- } \\
\text { tries, \% of extra-EU-28 } \\
\text { imports of services }\end{array}$ & 3.2 & 3.2 & 3.1 & 3.0 & 2.5 & 2.0 & 1.8 & 2.1 \\
\hline
\end{tabular}

Source: Eurostat and authors' calculations.

\section{Energy issues in the bilateral relations between the EU and Caspian countries}

According to the 2016 Energy Statistics Yearbook Iran has the largest proved recoverable reserves of natural gas (34 trillion cubic meters), Russia ranked 2nd (32), Turkmenistan 4th (10). Considering crude oil and natural gas liquids reserves Iran was 4th (21 billion metric tons) and Russia 6th (14). And Russia ranked 3th (35) by oil shale reserves.

According to the 2016 Energy Statistics Yearbook Russian Federation and Iran are among the leading crude oil producing (13\% and $5 \%$ of the world total) and natural gas producing countries (17\% and 6\%).

The table 6 shows that no EU member state is self-sufficient in energy. The highest self-sufficiency is Denmark (more than 90\%), while the lowest one is in Malta and Luxemburg (less than 5\%). Southern EU members are relatively less sufficient in energy, therefore there reasons for them to be the main interested parties in developing foreign energy supplies. On the other hand all the Caspian states have energy products in excess (primarily natural gas and oil) and are interested in markets for their sales. This is an important factor for cooperation between the two regions.

As we see in the table 7, a substantial part of primary oil and natural gas produced in the Caspian states is exported. On the other hand, if we consider for example the case of Greece, domestic production provided only $0,7 \%$ primary oil supply and $0.3 \%$ of natural gas supply. 
Table 6

Energy self-sufficiency of the EU and Caspian countries in 2016

\begin{tabular}{|c|c|}
\hline Country & Self-sufficiency in energy, \% \\
\hline Denmark & 90.9 \\
\hline Estonia & 83.8 \\
\hline Romania & 78.4 \\
\hline Sweden & 70.7 \\
\hline United Kingdom & 66.9 \\
\hline Poland & 66.7 \\
\hline Czechia & 65.6 \\
\hline Netherlands & 62.9 \\
\hline Bulgaria & 62.5 \\
\hline Latvia & 57.4 \\
\hline France & 53.7 \\
\hline Croatia & 52.4 \\
\hline Finland & 52.2 \\
\hline Slovenia & 52.0 \\
\hline Hungary & 44.5 \\
\hline Slovakia & 38.8 \\
\hline Germany & 37.3 \\
\hline Austria & 37.1 \\
\hline Ireland & 30.1 \\
\hline Greece & 29.1 \\
\hline Spain & 28.2 \\
\hline Portugal & 27.7 \\
\hline Belgium & 27.0 \\
\hline Lithuania & 25.9 \\
\hline Italy & 22.2 \\
\hline Cyprus & 5.9 \\
\hline Luxembourg & 4.3 \\
\hline Malta & 3.0 \\
\hline Azerbaijan & 406.0 \\
\hline Turkmenistan & 279.0 \\
\hline Kazakhstan & 202.0 \\
\hline Russian Federation & 187.9 \\
\hline Iran (Islamic Republic of) & 157.7 \\
\hline
\end{tabular}

Source: 2019 Energy Statistics Pocketbook. 
Table 7

The share of exports in the production of energy products in Caspian states in 2016

\begin{tabular}{|l|c|c|}
\hline \multicolumn{1}{|c|}{ Country } & Oil & Natural gas \\
\hline Azerbaijan & 85.2 & 43.0 \\
\hline Turkmenistan & 56.6 & 4.5 \\
\hline Kazakhstan & 78.1 & 35.4 \\
\hline Russian Federation & 47.0 & 31.0 \\
\hline Iran (Islamic Republic of) & 20.6 & 67.1 \\
\hline
\end{tabular}

Source: authors' calculations according to the data of 2016 Energy Balances.

According to the 2016 Energy Statistics Yearbook in 2016 most of the oil from Azerbaijan was exported to Italy (9.1 million metric tons) and Germany (5.2). Iranian oil was exported mainly to China (31.3), India (21.3), South Korea (14.0) and Japan (10.9). France was the main importer among the EU member states (4.5). The oil from Kazakhstan was exported mainly to Germany (8.5) and France (7.2). And Russian oil was exported mostly to China (52.5), Germany (33.1), the Netherlands (24.4), Poland (20.3) and Belarus (18.1). As for natural gas, Russia exported it mostly to Germany (1867 thousand terajoules), Italy (1022), Turkey (958) and Belarus (720). The natural gas from Turkmenistan was exported mostly to China (857). Now we see which countries may be the main drivers of the bilateral relations between the countries of the two regions.

\section{Modeling the EU's energy imports from the Caspian countries}

The correlation analysis showed that energy self-sufficiency does not affect the $\operatorname{In}(B F E)$, the correlation is only 0.03 . And the effect of distance is small and positive, although the t-test does in the regression not prove the effect of the distance. Therefore formula of the general gravity model is:

$$
\ln (B F E)=-10,506+1,196 \ln (G D P)+1,830 \ln (T F E)
$$

Or in non-logarithmic form:

$$
B F E 0,0000274 G D P^{1,1969} T_{F E}^{1,8309} \text {. }
$$


Also country-specific models are used to determine how different the EU demand for fuels from all the 5 Caspian countries is (see table 8). Total fuel exports are not included in the country-specific models. There is no separate model for Turkmenistan because too few cases with known data resulted is no significant effects found.

Table 8

Regression results for bilateral fuel exports of the EU countries

\begin{tabular}{|c|c|c|c|c|c|}
\hline $\begin{array}{l}\text { Regression } \\
\text { coefficients }\end{array}$ & $\begin{array}{l}5 \text { Caspian } \\
\text { countries }\end{array}$ & Azerbaijan & Iran & $\begin{array}{l}\text { Kazakh- } \\
\text { stan }\end{array}$ & $\begin{array}{c}\text { Russian } \\
\text { Federation }\end{array}$ \\
\hline Intercept & $\begin{array}{c}-10.506^{\star * \star} \\
(2.025)\end{array}$ & $\begin{array}{c}-2.552 \\
(3.884)\end{array}$ & $\begin{array}{c}-12.867^{* * *} \\
(3.097)\end{array}$ & $\begin{array}{c}1.202 \\
(2.024) \\
\end{array}$ & $\begin{array}{c}5.020^{\star \star *} \\
(1.191)\end{array}$ \\
\hline GDP & $\begin{array}{c}1.196^{\star * *} \\
(0.251)\end{array}$ & $\begin{array}{c}2.190^{\star * *} \\
(0.597)\end{array}$ & $\begin{array}{c}2.454^{* * *} \\
(0.521)\end{array}$ & $\begin{array}{l}0.668^{*} \\
(0.335)\end{array}$ & $\begin{array}{l}0.437^{\star \star} \\
(0.201)\end{array}$ \\
\hline TFE & $\begin{array}{c}1.830^{* * *} \\
(0.328)\end{array}$ & & & & \\
\hline ESS & & $\begin{array}{c}-2.398^{\star *} \\
(1.007)\end{array}$ & & & \\
\hline $\mathrm{R}^{2}$ & 0.310 & 0.364 & 0.471 & 0.166 & 0.153 \\
\hline F-Statistics & $25.55^{\star \star *}$ & $7.16^{\star \star \star}$ & $22.23^{\star \star *}$ & $3.98^{*}$ & $4.72^{* \star}$ \\
\hline $\mathrm{N}$ & 117 & 28 & 27 & 22 & 28 \\
\hline
\end{tabular}

Notes: Standard errors in parenthesis, t-test and F-test: ${ }^{* *}-p<0.01,{ }^{* *}-p<0.05,{ }^{*}-p<0.1$. Sources: authors' calculations according to the data of UNCTAD, World Bank and DistanceFromTo.

Almost all the models show that an importing country GDP is an important factor for bilateral fuel exports. Iran and Azerbaijan are likely to export to larger importing countries, and Russia and Kazakhstan and especially Turkmenistan export to more various countries. Exporting capacities are also an important factor. Distance turned out to be an insignificant factor in all the models. And finally energy self-sufficiency is usually insignificant except Azerbaijan which exports more to the countries with a deficit of domestic energy.

The results of cross-country analysis of undertraded and intensive bilateral fuel trade links are shown in the table 9. 
Table 9

Relative intensiveness of the bilateral fuel export links between the Caspian and the EU countries

\begin{tabular}{|c|c|c|c|c|c|}
\hline \multirow{2}{*}{$\begin{array}{l}\text { The EU im- } \\
\text { porting } \\
\text { countries }\end{array}$} & \multicolumn{5}{|c|}{$\operatorname{Ln}\left(B F E_{\text {actual }}\right)-\operatorname{Ln}\left(B F E_{\text {predicted }}\right)$ for the Caspian exporting countries } \\
\hline & Azerbaijan & Iran & Kazakhstan & Russia & $\begin{array}{l}\text { Turkmeni- } \\
\text { stan }\end{array}$ \\
\hline Austria & 3.8 & 1.5 & & -4.3 & 0.7 \\
\hline Belgium & $\begin{array}{l}-1.3 \\
\end{array}$ & -2.1 & 1.0 & 1.1 & 1.8 \\
\hline Bulgaria & 2.2 & -0.8 & 2.7 & 2.0 & 0.6 \\
\hline Croatia & 5.4 & 1.4 & 3.8 & 1.9 & \\
\hline Cyprus & 0.1 & -3.9 & 2.5 & 2.6 & 7.3 \\
\hline $\begin{array}{l}\text { Czech } \\
\text { Republic }\end{array}$ & 5.0 & -2.9 & & 0.9 & \\
\hline Denmark & -4.8 & -7.5 & & 1.5 & \\
\hline Estonia & -6.2 & -11.1 & 0.1 & 3.0 & \\
\hline Finland & -5.6 & -12.0 & 1.8 & 2.6 & \\
\hline France & 1.9 & 0.8 & 2.3 & -1.0 & -9.9 \\
\hline Germany & 2.3 & -2.3 & -1.8 & 0.2 & 0.6 \\
\hline Greece & 3.7 & 3.3 & 3.8 & 1.6 & 3.7 \\
\hline Hungary & -2.1 & 0.9 & 0.1 & 1.5 & 4.9 \\
\hline Ireland & -7.3 & -4.5 & & -0.4 & \\
\hline Italy & 4.6 & 1.4 & 3.6 & 0.2 & 1.2 \\
\hline Latvia & -1.2 & -6.0 & 1.5 & 3.7 & \\
\hline Lithuania & -5.2 & -5.2 & 4.6 & 2.9 & -3.9 \\
\hline Luxembourg & 3.3 & -12.4 & & -0.6 & \\
\hline Malta & 5.2 & -0.5 & 3.6 & 5.4 & \\
\hline Netherlands & 1.3 & 0.6 & 4.2 & 2.8 & \\
\hline Poland & -7.0 & -1.0 & 1.9 & 1.5 & 2.7 \\
\hline Portugal & 4.8 & -2.4 & 2.6 & 0.1 & \\
\hline Romania & 3.7 & -1.4 & 3.5 & 0.6 & 2.7 \\
\hline Slovakia & -5.4 & & & 2.2 & \\
\hline Slovenia & -4.1 & -7.0 & -0.5 & 1.0 & \\
\hline Spain & 2.5 & 1.5 & 2.1 & -1.0 & \\
\hline Sweden & -6.5 & -2.6 & 1.7 & 0.8 & \\
\hline $\begin{array}{l}\text { United } \\
\text { Kingdom }\end{array}$ & 1.2 & -3.6 & -6.6 & -0.7 & \\
\hline
\end{tabular}

Sources: authors' calculations according to the data of UNCTAD, World Bank and DistanceFromTo. 

and the countries of the Caspian Sea region

The fuel exports from Kazakhstan and Russia are rather successfully exploited, but the exports from Azerbaijan and especially Iran are undertraded. The EU countries which import fuels intensively from the Caspian countries in comparison to the the predicted value of trade are Malta, Croatia, Greece, the Netherlands and Italy. Ireland, United Kingdom, Estonia, Luxemburg, Slovenia, Finland and Denmark are the most undertraded importing destinations.

\section{Conclusions}

There are reasons both for cooperation and competition between the Caspian countries in the areas of international trade and especially energy supply. Russia is the main trade partner of the EU in the region and sought to have a leading role in the energy transportation from other Caspian countries. On the other hand the EU treated the Central Asia and Azerbaijan as an important source for energy supply diversification. Most previous studies discussed alternative routes involving transportation of natural gas and oil through Russia, Caspian Sea and Caucasus, and through Iran and Turkey.

The EU trade with the 5 Caspian countries is about 370 billion dollars. Despite the trade with the Caspian countries constitutes only about $3 \%$ of the total EU trade, the region supplies more than $1 / 4$ of fuel imports to the EU. The EU still has a deficit in it's the overall trade with the Caspian countries although there is a surplus in services trade contrasting with the trade deficit in goods.

Fuel exports to the EU are more than half of the trade between the EU and Caspian countries. Iran, Russia and Turkmenistan are among the leading countries by natural gas and crude oil proved recoverable reserves and production. All the Caspian countries are largely dependent on fuel exports. On the other hand none EU member state (especially South Europe) is self-sufficient in energy. This situation stimulates trade and energy cooperation between the two regions.

The trade links were influenced by trends in fuel prices, development of pipelines, in some cases sanctions and alternative fuel exports eastward. Nowadays exported fuels from Russia, Kazakhstan and Azerbaijan are mostly transported westward, and fuels from Iran and Turkmenistan - eastward. Regression analysis showed that bilateral trade in fuels between the analysed regions does not significantly depend on distance and in most cases on energy self-sufficiency of the importing EU countries. Instead the GDP as an indicator of the demand in the EU countries and export capacities of the Caspian countries are important determinants of energy supply routes. Comparing the actual bilateral fuel exports and the values predicted by the gravity model enabled us to determine the cases of the most successful routes of fuel supplies and undertraded routes. In particular Malta, Croatia, Greece, the Netherlands and Italy turned out to be among the 
most relatively intensive importers of fuels from the Caspian region. On the other hand Kazakhstan and Russia were among the most relatively intensive exporters to the EU.

\section{References}

1. Costel S. (2011). Future Developments on Oil and Gas Transport in the Black Sea Region. Constanta Maritime University Annals, 15, pp. 107-110.

2. DistanceFromTo (2019). Distance Between Cities Places on Map. Retrieved on August 19, 2019, from: https://www.distancefromto.net/

3. Emadi S.E., Nezhad H. (2011). Energy Market for Caspian Sea Oil and its Supply. IBSU Scientific Journal, 5(2), pp. 21-34.

4. Erdogdu (2010). Bypassing Russia: Nabucco Project and Its Implications for the European Gas Security. MPRA Paper 26793. Retrieved on June 28, 2019, from: http://mpra.ub.uni-muenchen.de/26793/

5. Eurostat (2019). Database. Retrieved on August 19, 2019 from: http://ec.europa.eu/eurostat/data/database/

6. Hannes (2010). The Resource Curse and Rentier States in the Caspian Region: A Need for Context Analysis. GIGA Working Paper No. 133. Hamburg: German Institute of Global and Area Studies.

7. Ibrayeva A., Sannikov D.V., Kadyrov M.A., Zapevalov V.N., Hasanov E.L., Zuev V.N. (2018). Importance of the Caspian Countries for the European Union Energy Security. International Journal of Energy Economics and Policy, 8(3), pp. 150-159.

8. Ikonnikova S. (2007). Games in the Eurasian Gas Supply Network: Multinational Bargaining, Strategic Investment and Hold-ups. MPRA Paper 17852. Retrieved on June 28, 2019 from: http://mpra.ub.uni-muenchen.de/17852/

9. Jahangir S. M. R. and Dural B. Y. (2018). Crude Oil, Natural Gas, and Economic Growth: Impact and Causality Analysis in Caspian Sea Region. International Journal of Management and Economics, 54(3), pp. 169-184.

10. Mangott G. (2010). EU Gas Supplies Security: Russian and EU Perspectives, the Role of the Caspian, the Middle East and the Maghreb Countries. Research Report 367. The Vienna Institute for International Economic Studies.

11. Koolaee E. (2011). Iran's Role in Energy Security at Regional and Global Levels. Iranian Economic Review, 15(28), pp. 95-115. 

and the countries of the Caspian Sea region

12. Locatelli C. (2010). Russian and Caspian Hydrocarbons: Energy Supply Stakes for the European Union. Europe Asia Studies, 62(6), pp. 959-971.

13. Popava V., Bagirov S., Grigoriev L., Paczinski V., Salikhov M., Tokmazishvili M. (2009). Energy Trade and Cooperation between the EU and CIS Countries. CASE Network Report 83. Warsaw: CASE - Center for Social and Economic Research.

14. Stanbekov T., Kotilko V. (2016). The Oil and Gas Complex of Eurasia: Problems and Prospects. The Bulletin of the Financial University, 2, pp.120-126. (in Russian)

15. World Bank (2019). World Development Indicators. Retrieved on June 28, 2019, from: http://data.worldbank.org/data-catalog/world-development-indicators/

16. UNCTAD (2019). Data Center. Retrieved on August 19, 2019, from: http://unctadstat.unctad.org/wds/ReportFolders/reportFolders.aspx?sCS_Ch osenLang=en/

17. United Nations (2019). Energy Statistics Pocketbook 2019. New York: Department of Economic and Social Affairs, Statistics Division. 